UDC 656.13:159.91

\title{
SOCIAL ORIENTATION OF ROAD SAFETY IN THE TRANSPORT PROCESS
}

D. Sc. (Tech.) O. Stepanov

\section{СОЦІАЛЬНА СПРЯМОВАНІСТЬ БЕЗПЕКИ ДОРОЖНЬОГО РУХУ У ТРАНСПОРТНОМУ ПРОЦЕСІ}

\author{
Д-р техн. наук О. В. Степанов
}

Abstract. The article considers the problem of social orientation of road safety taking into account the professional reliability of the driver in the transport process. It is shown that road traffic is a certain social process of society in which people's behavior is always determined by the social environment and in which road safety is of paramount importance. It is concluded that in the transport process, road safety is determined both by the basis of the professional reliability of the driver and the level of his or her "social adaptation". 
Keywords: road safety, transport process, professional reliability of the driver, social process, human factor.

Анотація. У статті розглядається проблема соиіальної орієнтації безпеки дорожнього руху з урахуванням професійної надійності водія в транспортному процесі. Показано, щь дорожній рух - ие певний сочіальний процес суспільства, в якому поведінка людей завжди визначається сочіальним середовищем і в якому безпека дорожнього руху має першорядне значення.

Аналіз джерел про професійну надійність водія автотранспорту дав можливість виділити його психофізіологічні причини, які знижують безпеку дорожнього руху і на які слід звернути особливу увагу. Слід зауважити, що безпеку дорожнього руху можна розглядати як спеціалізовану діяльність із запобігання аваріям у транспортному процесі. Така діяльність базується на відповідних підрозділах, які підтримують безпеку дорожнього руху. Профілактичні заходи ичих органів відрізняються своїм особливим призначенням із застосуванням спеціальних методів $і$ засобів.

Відповідно особливо важливим стає віктимологічний фактор учасника дорожнього руху в ДТП. Зрозуміло, шьо віктимологічна профілактика серед учасників дорожнього руху не $\epsilon$ панацеєю $і$ не вирішує всіх проблем. Віктимологічна профілактика не є абстрактною за своєю суттю, але постає як певна цілеспрямована система і спирається на фактор людини як учасника дорожнього руху. Водночас принципи побудови та функціонування иієє̈ системи мають иілком конкретну теоретичну та практичну спрямованість.

Зроблено висновок, щчо в транспортному прочесі безпека дорожнього руху визначається як на основі професійної надійності водія, так $і$ рівня його «соціальної адаптації». Актуальність висновку підтверджується не лише тим, щз він відповідає Стратегії на період до 2030 року, але й тим, шо Європейська рада з безпеки транспорту (ETSC) у Мальтійському меморандумі (січень 2017 р.) переглянула Директиви про початкові кваліфікації та підготовку водіїв автотранспортних засобів з урахуванням людського фактора.

Ключові слова: дорожня безпека, транспортний процес, професійна надійність водія, сочіальний прочес, людський фактор.

Introduction. According to the National Transport Strategy of Ukraine (hereinafter referred as the Strategy), which "determines the priorities of integrated transport policy... and the main directions of development of the transport sector for the period up to 2030 ..." [5], road safety (RS) is essentially a social issue. At the same time, road traffic is a certain social process of society, in which the behavior of people is always determined precisely by the social environment and in which road safety is of paramount importance. In this regard, the social orientation of the road safety in the transport process is one of the priorities of national security of Ukraine [5]. That is, the general social measures, the system of social regulation, management of social processes, "the widespread use of innovative technologies to ensure road safety..." [5] are meant.
Analysis of basic research and publications. In the scientific literature, the road safety is considered in different aspects, respectively, its concept has a different meaning [1, 5, 6, 8, 11]. Various scientific works of V.O. Alekseiev, S. I. Antypov, T. P. Hrechko, O. V. Bazhynov, V. O. Bohomolov, V. M. Varfolomieiev, M. Ya. Hovorushchenko, Ye.M. Lobanov, Ye. V. Nahornyi, $\quad$ V. P. Polischuk, M. A. Podryhalo, A. S. Polianskyi, A. N. Romanov, V. M. Samsonkin, V. Yu. Stepanov, A. M. Turenko and others. Are devoted to the issues of research of transport safety and road safety, to the general principles of ensuring the efficiency of transport. In scientific works, the authors point to the need to consider the safety of vehicles and road safety as a difficult, complex phenomenon characterized by certain internal and 
external processes. However, despite the large number of general works, it should be noted that the social orientation of the road safety, taking into account the reliability of the driver in the transport process requires further research.

The purpose of the study, problem statement. To consider the social orientation of road safety taking into account the professional reliability of the driver in the transport process.

Study materials. As noted in the Transport Strategy, "the level of transport safety, the amount of energy consumption and the impact on the environment in Ukraine do not meet modern requirements. Over the past

decades, a rapid increase in the number of vehicles and increase in traffic intensity has been observed in the world, which leads to the increase in the number of traffic accidents and

their negative consequences..." [5]. That is, activities to ensure road safety in the transport process are no exception. For road safety, the necessary social measures that give a preventive effect in order to eliminate the criminogenic factors to prevent road safety offenses.

In accordance with this, two areas merge: prevention of crimes (road traffic crimes) and prevention of administrative and legal violations (violation of traffic rules) [2, 3]. These areas are "included" in the system of crime prevention with the definition of the basic principles of construction and operation of this system and developed the appropriate concepts $[8,11]$. From the point of view of the social orientation of this warning, this is the fundamental legal principle of transport safety and road safety in the transport sector $[2,3,8]$.

Note that the safety of transport and road safety in the transport process runs through the entire social component of legal measures to

combat the offense of road users (RU). It

permeates all measures aimed at preventing unlawful human behavior in order to prevent road accidents.

Specifying the concept of "prevention of offenses", which are made by the road user, one should pay attention to the fact that it is aimed at preventing violations of legal norms, and determines the social significance of this warning. In this regard, a kind of law enforcement activity is being streamlined to ensure "order on the roads" within the framework of criminal law and criminal procedure [3].

It should be emphasized that road safety can be considered as a specialized activity to prevent accidents in the transport process. Such activities are based on the relevant units that support the road safety. Preventive measures of these bodies differ in their special purpose, with the use of special methods and tools $[2,8]$.

Accordingly, the victimological factor of the road user in the road accident becomes especially important [10]. It is clear that victimological prophylaxis among the road users is not a panacea and does not solve all problems. Victimological prevention is not abstract in nature, but looks like a certain purposeful system and relies on the factor of human as the road user. At the same time, the principles of the construction and functioning of this system have a very specific theoretical and practical orientation. If this system is understood as a kind of theoretical scheme, the provision of the road safety in the transport process in practice is considered as the applied activity, as the methodological orientation of practice to solve the specific problem - road accident prevention.

Based on this, the question arises about the objects of the precautionary measure of influence. In this regard, we can distinguish two directions of precautionary measures: victimogenic situations and potential victims of road accidents. When implementing the first of the directions, special attention should be paid to measures that are aimed at eliminating victimogenic situations and immediately preceding road accidents. This is due to the moral, psychological and social characteristics of road users. In the implementation of the second direction it is necessary to carry out measures of educational influence and legal promotion of the road safety $[4,9]$. In addition, to carry out professional training of drivers of motor vehicles (MT) to educate their professional reliability as a factor in the safety of transport and road safety in the transport process. 
The analysis of sources on professional reliability of the driver of the motor vehicles gave the chance to allocate its psychophysiological reasons which reduce the road safety and to which it is necessary to pay special attention:

- imperfection of the driver's motivational sphere (DMS) - deliberate execution of the driver's actions to control the motor vehicle, non-observance of traffic rules;

- imperfection of the driver's motivational sphere, low professional readiness of the driver for safe driving of the motor vehicle - deliberate execution of actions to control the motor vehicle, non-observance of traffic rules, errors in driving;

- imperfection of the driver's motivational sphere, low professional readiness of the driver for discretion - deliberate execution of actions to control the motor vehicle, non-observance of traffic rules and errors in discretion;

- imperfection of the driver's motivational sphere, low professional readiness of the driver for road orientation - deliberate execution of actions to control the vehicle, nonobservance of traffic rules and errors in road orientation;

- imperfection of the driver's motivational sphere, low professional readiness of the driver to interact - deliberate execution of actions to control the vehicle, nonobservance of traffic regulations and mistakes at interaction with other road users;

- low professional readiness of the driver to safely drive the motor vehicle - errors when driving the motor vehicle with violation of traffic rules or inappropriate behavior;

- inadequate professional readiness of the driver - reduction or loss of professional ability to work.

The above allows us to assert that the safety of transport and road safety in the transport process depends on the human factor - the psychophysiological reliability of the driver. Accordingly, the following classification of psychophysiological causes of road accidents is formed.
The first psychophysiological reason is low driver reliability, which can be expressed through: low driver qualifications; decreased motivation to work; inability of the driver to assess the road situation in a timely manner; insufficient training in road traffic accidents; unpreparedness in the psychology of driving the motor vehicle; decrease in the state of professional ability to work.

The second psychophysiological reason is the professional reliability of the driver. It is a set of necessary knowledge, skills and abilities that provide effective and safe driving of the motor vehicle in emergency road situations. Professional reliability of the driver includes three components: technical reliability; preparation for the specific trip; psychological reliability. The latter includes the necessary knowledge of the driver about himself, his own capabilities and limitations, methods of control and management of the functional state, the causes of incorrect decisions, prevention of errors and violations, and others. The decrease in the psychological reliability of the driver can be manifested in the following: low qualification of the driver; insufficient training in road traffic accidents; psychological unpreparedness when interacting with other road users, etc. That is, in modern road conditions, the importance of psychological reliability of the driver increases significantly. In conclusion, these components of professional reliability should be additionally included in the program of training the motor vehicle drivers in driving schools.

The third psychophysiological reason that forms the potential for driver reliability is the state of professional efficiency. This is the integral property of the driver, which depends on the level of functioning of the mental and physiological systems of the driver. It determines his ability to safely drive the motor vehicle for the required time. Professional efficiency is determined by the state of health and reserve capabilities of the driver's body. In violation of these characteristics, there is either a decrease or loss of professional efficiency of the driver. 
The fourth psychophysiological reason that determines the potential of driver reliability is the development of driver quality training, which determines his ability to master the profession.

Other causes of road accidents - technical malfunctions of the motor vehicles, a condition of highways, environment, criminal activity of the road user, etc.

It is known that before starting training at the driving school, candidates for driving motor vehicle undergo a medical examination. It allows to exclude persons who do not meet the established regulatory requirements for the driving motor vehicles for health reasons. The psychophysiological qualities of future drivers are not evaluated. As a result, some of them may have insufficient driver's psychophysiological reliability (DPR) to safely control the motor vehicle in the transport process.

The analysis of psychophysiological reasons for the implementation of accidents by drivers and their assessment allows us to consider driver's psychophysiological reliability as the indicator of the human factor. In this regard, a set of characteristics of the driver, such as: state of the driver's motivational sphere, level of professional reliability, state of efficiency, level of development of professional qualities of the driver should be attributed to the complex indicator of the factor of the driver's professional reliability - DPR.

The psychology of the road user and in particular drivers in the transport process is based solely on the road safety. In addition, the analysis of the content of the theoretical exam for future drivers shows that the questions that allow to determine the level of knowledge in the field of culture of behavior and psychology of the road safety and safe driving of motor vehicle are not provided [4, 7, 9].

Note that in the transport process the road safety is largely determined by the basis of psychophysiological characteristics of the driver, and the level of his "social adaptation". All this ensures the adequate human response to factors of the road situation and environmental factors of the DVRE system. Accordingly, one of the main reasons for drivers' mistakes is the low quality of special and psychological training at the driving school and the development of motor vehicle driving skills.

Thus, we can come to the conclusion that the genesis of the road safety violations is based on failures of complex sensorimotor reactions of a person. In particular, the failure of the central neuropsychological mechanisms of regulation of the automated motor professional skills of the driver.

It should be noted another reason that affects the road safety due to the professional reliability of the driver. In driving schools, when analyzing the road safety problems, there is no classification of psychophysiological causes of accidents, which is associated with the physiological characteristics of the driver. Without a doubt, this drawback is a consequence of the imperfection of training programs for future drivers, who do not receive sufficient information about the psychological reasons for non-standard driver actions in extreme situations.

To this we add that when analyzing the causes of road accidents, experts do not take into account the mechanism for determining the psychological causes of events to identify the personal shortcomings of drivers and other road users. That is, there is no feedback between the actions of drivers and their personal characteristics, which negatively affects their professional reliability and, as a result, the safety of the motor vehicles and road safety in the transport process.

In addition, the minimum training time in driving schools on the psychology of safe driving of the motor vehicles can be considered as a systemic and dangerous factor in the road safety. Obviously, this is one of the main contradictions at the present stage of training future motor vehicle drivers.

Taking into account the above and in order to prevent road accidents, it is proposed to include in the driver training program the following issues: psychological features of the motor vehicle driving; psychological dangerous factors in the motor vehicle driving; psycho- 
logical features of interaction between the road users; psychological analysis of driver errors; psychological causes of road accidents, etc.

Thus safety of the motor vehicle is connected not only with the condition of motor skills of the driver but also with erroneous programs of behavior and inability to control himself in transport process. In particular, keeping the distance, driving into the oncoming lane, exceeding the set speed, as well as ignorance of the psychological hazards of other road users. To this we add that the training programs for future motor vehicle drivers do not consider the private activities of the driver, taking into account the complex of psychological training.

Accordingly, consider some of the driver's private activities while driving the motor vehicle.

Safety of the motor vehicle in the transport process. The content of this activity is the safe work of the driver in accordance with the information received from the systems of motor vehicle. The sources of information are both instrument readings and other signals (noise, vibration, acceleration, smell, etc.). The formation of skills to perform this activity should be carried out on the site. When driving outside, the conditions of their practice become more complicated (other types of activity are added), and the quality of education deteriorates. Such activities are connected with such road accidents as collision with the pedestrian while confusing the pedals (pressing "gas" instead of "brake"), collision with another motor vehicles during its braking, etc.

Compliance with traffic regulations and prevention of collisions with objects is defined as precaution. The content of this activity is represented by traffic regulation, objects that may violate the road safety, as motor vehicle in accordance with the requirements of regulatory means - signs, traffic lights, markings, etc. This is the highest priority in the safe driving of motor vehicle. Of course, practicing the skills of its implementation is possible when modeling road conditions. But, unfortunately, this activity in the training of drivers is practically not considered.
The motor vehicle position on the road road orientation in the transport process. The content of this activity is to determine the current state of the motor vehicle in relation to road landmarks (marking, road edge, roadside, etc.) and its correction. After graduating from the driving school, drivers learn about this activity only in practice, when, being in a traffic flow, they face negative environmental factors - snow, rain, fog, lack of road markings, etc. The formation of road orienteering skills allows drivers to feel the importance and complexity of this activity when changing the driving conditions of motor vehicles. For example, because of poor visibility of the road or at a snow covering of the road, because of shifts in other row, especially during turning, etc.

Location of motor vehicle in relation to significant landmarks - conducting orienteering on the site. The content of this activity includes determining the location of the motor vehicle and its correction. This is a private activity, making a driver from a small settlement a "novice at the wheel" when driving through a metropolis. Practice of skills of performance of this activity can occur only during driving motor vehicle on the unfamiliar route. Without the ability to navigate the terrain to master this activity is extremely difficult.

Creating optimal conditions for drivers and other road users. The content of this activity includes: the use of alarm; control of the motor vehicle taking into account other drivers; reaction to signals by the road users, etc. This activity determines the driver's culture and knowledge of traffic rules. The formation of skills for its implementation occurs when driving motor vehicle on the street. The following accidents are associated with the ineffectiveness of the organization of interaction: collision with other motor vehicles during the lane change without the warning switch on the direction indicator; hitting a pedestrian who began to cross the street, etc.

Complications of the road situation, preventing the development of the emergency situation on the road. The content of this activity includes: detection of the emergency situation on the road; situational assessment; recognition of 
the special situation on the road; decision making; decision execution and control, etc.

Thus, taking into account the human factor, you can determine the content and structure, get a set of private activities and justify the rational approach to the road safety. That is, the complex activity of the driver is a set of private activity of the driver of the motor vehicle which is directed on achievement of the general final purpose - safety of the motor vehicle and road safety, prevention of road accident.

Conclusions. Summing up the study of social orientation and reliability of the driver, we conclude that one of the ways to ensure the road safety in the transport process is to develop a modern methodology for driver training. It should focus on improving the professional reliability of drivers by improving the mechanism of preventive action taking into account the human factor.

The relevance of the conclusion is confirmed not only by the fact that it is in line with the Strategy for the period up to 2030, but also by the fact that the European Transport Safety Council (ETSC) in the Maltese Memorandum (January 2017) initiated a revision of the Initial Qualifications and Training Directive for Motor Vehicle Drivers taking into account the human factor [1]. In particular, the formation of the single information and analytical support of the road safety, but this is a matter of further research.

\section{References}

1. ETSC 2012. Підходи до безпеки дорожнього руху: від оцінки ризику до навчання. URL: information@etsc.eu.

2. Кодекс України про адміністративні правопорушення. Харків: Парус, 2008. 252 с.

3. Кодекс України про кримінальні правопорушення (із змінами та доповненнями). Харків: ТОВ «Одіссей», 2008. 288 с.

4. Лончинский Б. Ф. ДТП. Ошибки водителей, приведшие к их возникновению. Сарма, 2005. $104 \mathrm{c}$.

5. Про схвалення Національної транспортної стратегії України на період до 2030 року: розпорядження Кабінету Міністрів України від 30 травня 2018 р., № 430-p. URL: https://zakon.rada.gov.ua/laws/show/430-2018-\%D1\%80\#Text.

6. Daniele Stam, Adriano Alessandrini. ARTS for Last-Mile Transport Designing and Integrating in Cities. Implementing Automated Road Transport Systems in Urban Settings. 2018. Chapter 2. P. 17-80. URL: https://doi.org/10.1016/B978-0-12-812993-7.00002-4

7. Романов А. Н. Автотранспортная психология. Москва: Изд. центр «Академия», 2002. $224 \mathrm{c}$.

8. Транспортне право України / М. Л. Шелухін, О. І. Антонюк, В. О. Вишнивецька та ін.; за ред. М. Л. Шелухіна. Київ: Вид. Дім «Ін Юре», 2008. 896 с.

9. Усольцева И. В. Психологические основы безопасного управления транспортным средством. Автополис. Саратов, 2009. 240 с.

10. Франк Л. В. Виктимология и виктимность. Душанбе: ОАО «Кафкак», 1972. 577 с.

11. Центр безпеки дорожнього руху та автоматизованих систем. Aварійність на автошляхах України. URL: http://www.sai.gov.ua/ua/people/5.htm.

Stepanov Oleksii, D. Sc. (Tech.), professor, organization and road safety Department, Kharkov National Automobile and Highway University. ORCID iD: 0000-0003-4954-2532.E-mail: cc_7@ukr.net.

Степанов Олексій Вікторович, д-р техн. наук, професор кафедри організації та безпеки дорожнього руху Харківського національного автомобільно-дорожнього університету. ORCID iD: 0000-0003-4954-2532. E-mail: cc_7@ukr.net.

Статтю прийнято 25.01.2021 p. 